OPEN ACCESS

Edited by:

Victoria Hurth

University of Cambridge

United Kingdom

Reviewed by:

Alison Green,

Scientists Warning Foundation,

United States

Federica Murmura,

University of Urbino Carlo Bo, Italy

${ }^{*}$ Correspondence: María Carmen López-López mclopez@ugr.es

Specialty section: This article was submitted to

Sustainable Organizations,

a section of the journal

Frontiers in Sustainability

Received: 17 January 2021 Accepted: 08 March 2021

Published: 01 April 2021

Citation:

López-López MC, Martínez-Rodríguez FM and Fernández-Herrería A (2021) The

University at the Crossroads of Eco-Social Challenges: Pedagogy of Care and the Community of Life for a

Transformative Learning.

Front. Sustain. 2:654769.

doi: 10.3389/frsus.2021.654769

\section{The University at the Crossroads of Eco-Social Challenges: Pedagogy of Care and the Community of Life for a Transformative Learning}

\author{
María Carmen López-López ${ }^{1 *}$, Francisco Miguel Martínez-Rodríguez ${ }^{2}$ and \\ Alfonso Fernández-Herrería ${ }^{2}$ \\ ${ }^{1}$ Department of Didactics and School Organization, University of Granada, Granada, Spain, ${ }^{2}$ Department of Pedagogy, \\ University of Granada, Granada, Spain
}

What kind of responsibility do universities have with regard to the current emergency created by ecological and socio-economic collapse? This work begins by considering the colonization of universities by neoliberal globalization. Education is one of the areas that appears as a fundamental source of business in the globalized economy, thus reorienting the role of the State in accordance with the New Public Managements (NPM's) educational policy. The NPM is the main instrument responsible for modifying the structure and culture of state services by means of introducing privatization and market-specific mechanisms. But, in so doing, something very important is created: a process of "re-culturing," the establishment of the "one-track thinking." It is "endogenous neoliberalism" that promotes the construction of a new identity: the neoliberal view of education from the "entrepreneurial self." Next, and based on the criticism of the Frankfurt School, we question whether the use of reason-as instrumental reason-exists in neoliberal logic, and how it use is related to morals and ethics. We need alternative ideas that configure a new worldview for a new scenario, one which facilitates a deep civilizational reconstruction. The Community of Life is the fundamental certainty on which we can base a new worldview. We are one human family and, even more, one Earth Community with a common destiny. This perspective exists at an even more inclusive level, in order to integrate all living beings. We need care for the community of life with understanding, compassion, and love. It implies a synthesis, which places us at the doors of wisdom. The ethics of care and its educational translation as Pedagogy of Care, should have, as its main objective, the experiential learning of our reconnection with the Community of Life. Therefore, it would be necessary a truly transformative learning that we, as humanity, will need to carry out. This is where universities are called on to play a strategic role. The changes that must take place in universities have to be based on a new worldview: the Ethics of Care of the Community of Life. Finally, some practical consequences are proposed in this sense.

Keywords: university, neoliberalism, community of life, ethics of care, transformative learning, worldview 


\section{INTRODUCTION}

What kind of responsibility do universities have with regard to the current emergency created by ecological and socio-economic collapse? How should universities reorient themselves in order to establish a benchmark for achieving a sustainable lifestyle? We argue that universities must rethink their role and commitments, because neoliberalism has had a profound impact on higher education around the world, considering it a source of business. Universities should become aware of this neoliberal colonization if they want to lead the transition toward a more sustainable and equitable society. Next, looking more in depth, and based on the criticism of the Frankfurt School, we question whether the use of reason-as instrumental reason-exists in neoliberal logic, and how its use is related to morals and ethics, as understood by humanistic psychologists. This, as will be shown, is an important issue if we want to act from ethics. The perspective is deconstructive.

However, we need to advance positive responses. What can we do? We have one uncertainty and three certainties. The uncertainty refers to our ignorance about what kind of world will replace the progressively decaying capitalism of post-modern globalization. There is an interesting proposal to consider which is being assumed by the European Union and other countries. We refer to that which appears in Jeremy Rifkin's latest publications. If this proposal were to materialize, it would give rise to the third industrial revolution which would have socio-political and economic characteristics very different from the previous ones. However, now what we have is the capitalism of the postindustrial, "liquid" (Bauman) society, the capitalism of the risk society (Beck, Giddens).

We need courageous and alternative ideas that configure a new worldview for a new scenario, one which facilitates a deep civilizational reconstruction. This is where universities are called on to play a strategic role. The university, as an institution, should promote this new worldview with the certainty that, when there is a conjunction of suitable new ideas and the opportune moment in the crisis-in a humanity which already operates as a single learning subject-, these ideas will have unstoppable power.

We intend to outline the elements which we believe should be present in this new worldview, and we express them through three certainties:

1. The central and inspiring value of the Community of Life (with scientific certainties such as the Gaia Theory, or approaches as the ethics of care, a pedagogy of care...). Everything should be redefined from the perspective of the Earth's community, human beings being the ethical thread, in charge of the fabric of life.

2. The need for a true commitment that is both intercultural and inclusive, can be shared in different worldviews which allow us to respond to the complex challenges posed. The need for a true intercultural, and inclusive, commitment in order to share different worldviews which allow us to respond to the serious challenges we face. We refer, here, to indigenous cultures and traditional Eastern Philosophy. Diversity brings a wealth of perspectives.
3. The third certainty (related to the second) refers to the consideration of reason in modernity, which limits the diversity of perspectives sought by its rationalistic colonization of mind. We also need other intelligences (socio-emotional, ecological, and spiritual). Consequently, rational knowledge alone is insufficient. This "confession" opens the doors to something new: wisdom. This is a subject introduced by Nicholas Maxwell, who, in addition to knowledge, proposes research, and development of wisdom in universities. We urgently need this wisdom which brings us back to the central subject, which that of is the individual.

In this context of global change we are committed to two strategic elements of a general nature. They are closely related, and are key in order to create practical changes in universities. The first is that we should not fight against the neoliberal system. We should apply Taoist principles-hence the importance of approaching other cultures-and adopt the methods of martial arts, like judo, which are based on defense and in which the strength of the rival is used to destabilize the opponent. In this way, the action-reaction principle would not give energy to this already decadent neoliberalism. Thus, we would avoid wasting our energy which we could then use for those creative actions which are so necessary for the creation of the world that we want to see born.

The second strategic element involves referred uncertainty: we do not know what kind of world will replace that of globalized capitalism. Let us "turn toward the individual" because we know what the human beings, who will build this new world, should be like. These ideas are developed in this paper.

\section{THE COLONIZATION OF UNIVERSITIES BY NEOLIBERAL GLOBALIZATION}

The academic world, should exercise a clear form of ethical and scientific leadership in the face of the serious global socioecological crisis. We have, therefore, to examine the neoliberal "pollution" which has deeply colonized higher education around the world by perceiving it as a source of business within today's knowledge economy (Goodman, 2012; Commisso, 2013; Maisuria, 2014; Uzuner-Smith and Englander, 2015). In the final third of the last century a series of economic, political, and cultural transformations took place. They acquired a strong role in all of society and were grouped together under the term "globalization." More and more social spaces submitted to the mercantilist logic of economic benefit, privatizing public companies and social services, and cutting budgets which financed the Welfare State. For the economic benefit to multiply, this neoliberal philosophy must reach the entire society. So, under this system, public institutions are required to be managed like private entities, but with public money (Navarro, 2007). According to Harvey (2005, p. 19) neoliberalism has historically manifested itself "as a political project to re-establish the conditions for capital accumulation and to restore the power of economic elites." In order to create a suitable environment for 
the accumulation of world capital the New Public Management (NPM) was born.

As Kincheloe (2007) argues, the privatization of state educational institutions has resulted in them being strongly mediated by economic powers. This is because they are perceived as corporations that must engage with the logic of the free market like private companies. Under this outrageous attack by the forces of privatization, students have become consumers of education, rather than citizens. Furthermore, the educational institution becomes a company specializing in issuing degrees. This view of education as a business, as a mere commodity, reflects what lies at the very heart of the NPM, which is based on the "three E's:" efficiency, effectiveness, and economy.

According to Ball and Youdell (2007, p. 23), the NPM is the main instrument responsible for modifying the structure and culture of state services by means of introducing privatization and market-specific mechanisms. But, in so doing, something very important is created which affects "how" and "where" decisions are made, without consulting education professionals. These professionals are subjected to new forms of control, through performance management systems, encouraging them to identify with other types of commitment and priorities. This is what these authors call a process of "re-culturing." The NPM, as a form of neoliberal colonization, is present in university operations where forms of business management are applied to the public sector. Its characteristics are: accountability (early assessments, classification, quantification, accreditation, standardized tests, performance criteria, orientation toward excellence, and stratification of achievements). It also involves privatization and outsourcing of services, decentralization, perceiving the student as a client, strategic planning, organizational, and management flexibility. In addition, it implements market mechanisms, in particular those related to competitiveness and incentive (prizes and penalties), profitability, weak public administration, focus on competencies, emphasis on results rather than processes, budgetary cuts ... (Gruening, 2001; López-López and Crisol, 2020).

It is about providing an educational level that allows them (students) to find jobs. The objective of education will not, therefore, be the full development of the human personality in respect for the democracy principles of coexistence and fundamental rights and freedoms (Bernal and Vázquez, 2013, p. 49).

What is sought is the subversion of the ethical order of things: integral training so that we are critics and owners of our lives, understanding that economy is a means at the service of human ends is not sought. Rather, the intention is that citizens rebuild themselves as clients thus aligning with the economic interests dictated by the market. All of this reframes the identity of students and teachers, and marks them ontologically and epistemologically. In this way, neoliberalism creates a profound impact on higher education throughout the world (Hursh and Wall, 2011), leading to a global homogenization of educational systems, but without eliminating the nuances of each state. Thus, they promote processes which are focused on results, on standardized assessments and, consequently, on credentialing (Martínez-Rodríguez et al., 2018).

De Lissovoy (2013) points out that there is an ideological effect which is very dear to neoliberal philosophy: the establishment of the "one-track thinking." It seeks to spread the belief that there is no hope of another possible world, and thus assumes with resignation, the "inevitability" of neoliberal capitalist globalization as the only ideology.

This imposition of one-track thinking manifests itself as the "natural" way of perceiving social and institutional realities. It, therefore, becomes neoliberal common sense (Leistyna, 2007). This implies an extraordinary triumph for the ideological dimension of globalization. It has universalised the interests of capital, to the detriment of the interests of labor, and those of the global economic forces that support it (Harvey, 2005). By showing itself as "natural," it renders its true nature invisible: a self-interested social construction; that is, a way of seeing reality which is internalized and which already has its own dynamism. It is "endogenous neoliberalism," which grants privilege to the rationality of the market, erodes the pre-existing forms of selfgovernment, and the "relative autonomy" of academic work (Commisso, 2013). From within the context of this internalized view, education is no longer a public good, but a business, a good for individual consumption, a private good, one more commodity (Bauman, 2008).

Neoliberal "common sense" is the springboard from which what needs to be seen, and how to be seen, is imposed. In our market society, the rules of the market are the foundation which establishes the essential meaning of our vital reality. This meaning has been internalized. Therefore, it is no longer essential for the neoliberal agenda to continue working on the construction of identities within the context of the logic of the market. This is because we have it inside us, like a "Trojan horse." Foucault (2008) calls this "biopolitics," a term used to designate the exercise of power, not over territories but over the lives of people and populations (biopower). As argued by Hellberg and Knutsson (2018), when referring to a statement by Peters (2007), biopolitics is the ability to govern without the governed subjects perceiving that they are being governed. We do not need to be governed from the outside as we already govern ourselves. Neoliberalism, with its "one-track thought," promotes the construction of a new identity: the neoliberal view of education from the "entrepreneurial self" (FernándezHerrería and Martínez-Rodríguez, 2016).

According to Olssen and Peters (2005, p. 315), "in neoliberalism the state seeks to create an individual that is an enterprising and competitive entrepreneur." University education is reconstructed from this perspective. The state, like the university, serves the interests of the market, favoring individual initiative, competition, and self-interest (even "selfexploitation") over collective interest. Thus, it creates a series of rules, laws, and institutions that help to rebuild the individual as a consumer. According to Darder (2012), education, in general, becomes new benchmarks for neoliberal strategy. Canaan (2013) argues that a "deep neoliberalization" is taking place because neoliberal policies are instrumentalizing supranational organizations such as the European Union. Thus, they 
are dismantling the Welfare State and commercializing various state institutions, including universities. Loh and $\mathrm{Hu}$ (2014) state that economic globalization is the new context which redefines the role of the state, putting it at the service of large trans-national corporations and guaranteeing opportunities for entrepreneurship initiative, competition, and profit.

Applying these neoliberal values to the field of education shows that they are completely consistent with the goal they aim to shape. Furlong (2013) maintains this is a prototype of a highly competitive form of "human capital" in order to put it at the service of a globalized economy. "To shape" must be understood in a deep sense, since it has become obvious that neoliberalism intends to build a new identity, that of the "entrepreneurial self." This is like a business project in which individuals govern themselves throughout their lives. According to Du Gay (1996) this new identity, created by globalization, has changed the lives of individuals and the nature of organizations, including universities. Concepts such as incentives, revenue, quality, nonstandardized services ... are redefining more entrepreneurial and less mechanistic organizational forms, that is, less bureaucratic forms, from the traditional perspective. Bureaucracy, understood as behaviors adapted to situations of stability, becomes the first victim of an uncertain environment created by globalization. The new bureaucracy is flexible. From the perspective of neoliberal rationality the individual must be receptive to the changes that occur in their environment. In this sense the concept of company, according to this author, is a key element in the discourses relating to organizational reforms. What is actually being proposed is a universalization of the model of a "commercial company" to any form of organization, including universities, and also individuals.

It is obvious that this new neoliberal governmentality perceives the individual as an inherently manipulable construction, characterized by behavior control by means of changes in the environment. This is behaviorism. "In other words, entrepreneurial government 'makes up' the individual as a particular sort of person-as an 'entrepreneur of the self"' (Du Gay, 1996, p. 156). Here, Du Gay takes up an idea, put forward by Foucault in the late 1970s, which is that of the individual as an "entrepreneur of the self," in other words an entrepreneur of him/herself. This means that, regardless of their personal circumstances, identity assumed by these individuals is that life, understood as a business, is dedicated to a unique undertaking: preserving, rebuilding, and increasing their own human capital. The individual is, therefore, the only one responsible for their successes and failures in the "business of life." So there are no structural responsibilities and there are no socio-economic or ecological injustices.

Within the neoliberal identity of entrepreneurial self, we find, among other features, a strong sense of individualism, a self driven by profit, a way of life defined by conquest, control, and utilitarian view, a concept of nature - from which one is disconnected - as a store of resources. In addition, it has a notion of time which relates to the service of material necessities (Fernández-Herrería and Martínez-Rodríguez, 2016, p. 317).
According to Han (2019), and in line with Foucault's "society of disciplinarity" of today, we are in the "performance society." Here, competition takes on its full meaning. Through it the performance subjects give meaning to their lives and project themselves into the future seeking to achieve greater personal and professional "successes" through the valorization of effort. They move from subjects of "obedience," due to external conditions, to subjects of "performance" who exist in a "selfexploiting relationship." The performance subject continues to be disciplined, but has shifted from that external conditioning factor of Foucauldian "duty" to an internal "power" which is focused on always achieving more. This causes all kinds of disorders (stress, occupational burnout syndrome, anxiety, depression ...). This is what Han calls the "burnout society" which is increasingly colonizing university life.

\section{LOOKING DEEPER: NEOLIBERALISM AND INSTRUMENTAL REASON MORALS AND ETHICS}

Thinkers from the Frankfurt School elaborated on the concept of instrumental reason in far reaching works such as Horkheimer's Critique of Instrumental Reason and Horkheimer and Adorno's Dialectic of Enlightenment (1947). They highlight the dark side of Modernity: the world wars, Stalinism, the extermination camps ... everything that humanity is paying for in the supposed advancement of "progress," which threatens to destroy what it was trying to realize: the idea of man. The central thesis of Horkheimer and Adorno's book is that the holocaust is not exactly a coincidence, but an ideological consequence of the way in which the West, and all its power, has been constituted (Horkheimer and Adorno, 2002). It has been shown that irrationalism is not a phenomenon which is typical of the most prominent political totalitarianisms; rather, that it is deeply rooted as a "civilizing" process, hidden under the mask of reason.

Freeing man from the influence of irrationality was the goal of the bourgeois philosophy of the Enlightenment. Kant's sapere aude (dare to know, to think), Condorcet's highly optimistic picture of the progress of the human spirit, based on science, and with no guidance but reason, has led us to a time when promises and realities fail to correspond. In this sense a critique of Enlightenment is a critique of thought. According to Horkheimer and Adorno (2002, p. 2), what is understood by reason functions as a mechanism of dominance: "What human beings seek to learn from nature is how to use it to dominate wholly both it and human beings. Nothing else counts." Reason has become instrumental reason. This began with the birth of science in the sixteenth and seventeenth centuries.

Since then, it has shown a desire to dominate. Reason has become technical, focused on the usefulness of actions as a means to an end. The end result is what matters, not the means used. It is a pragmatic reason: the important thing about anything is what it is for. Instrumental reason falls into objectification by turning the realities it deals with into objects or instruments; in other words, into "means to an end" which it neither establishes nor poses. Horkheimer and Adorno denounced this split between 
ends and means. As a result instrumental reason ends up being a blind, pragmatic thought. It renounces examination, the pursuit of the truth and the ethics of the end to which it serves. Thus, it reproduces the status quo and serves domination. This is the disease that has taken hold of a reason which has been reduced to a mere instrument limited to the uncritical acceptance of reality. The Enlightenment, with its rationalist mechanistic worldview, developed a concept of reason as an instrument for the domination of nature and human beings. As Comins (2016, p. 135) argues, this concept of reason "was perfectly adapted to the exploitation requirement of nascent capitalism, as authors such as Carolyn Merchant (1980, p. 182) and Shiva (1991, p. 45) have sharply denounced." The positivism of the nineteenth Century led this worldview to its final outcome, presenting it as the only possible worldview "which has accompanied not only the industrial revolution, but also the development of capitalism and globalization" (Comins, 2016, p. 134).

The exercise of instrumental reason is expressed in the technical rationality of current societies and their alienation. The individual ends up being a mere thing, just a cog in the mechanism of the economy, reducing him/her to a mere official. The individual no longer needs to make decisions about what to do, as for this there are institutions and mass culture. The world of economics, of instrumental reason, has its own dynamism. It governs itself independently of individuals in order to impose its dominion over them, to serve the interests of the objectifying mechanisms of the anonymous, capitalist, and impersonal economic apparatus.

From this heartless form of knowledge, from this instrumental, functional, analytical-mechanistic reason, the programme of Modernity arises. It converts knowledge into power which is expressed by domination of nature, women, peoples, and cultures. It takes shape as colonialism, slavery, machismo, ecological depredation, and aversion to the different.

This is what it was hidden in capitalist industrialism which becomes neoliberal globalization: a change in worldview in which reason appears as an instrumental reason. In its nature reification is found as an instrument of domination. The crisis of modernity is the crisis of the Enlightenment project. Now we are in the final phase of this barbarism with its global ecological-social challenges, before which we question what the university can do. It cannot be said that history has failed to show the successes or errors of human projects when they are allowed to flow along the river of time.

\section{MORALS, ETHICS, AND BUREAUCRATISM}

The Enlightenment project, with its claim to rescue the human being from barbarism, has chosen the external path in order to realize progress, instead of advancing and delving into the knowledge and development of human nature itself. Is this a way of externalizing the need for an unmet inner journey?

Indeed, humanistic psychology speaks of the process of "individuation" of the human being (Erich Fromm, Viktor Frankl, Abraham Maslow, Carl Rogers, Carl Jung ...). It refers to the vital unfolding in which individuals take control of their own personal development. It is a process that gives meaning to people's lives and cannot be carried out by anyone other than that person. In this way one builds from autonomy. Conversely, this sphere of freedom is the one that frightens human beings the most. Fromm raises this, particularly in his work, The Fear of Freedom.

This self-construction is done from ethics, which travel along the same path as that of individuation, involving autonomy, selfawareness, inner work, commitment to self-realization. It means taking responsibility for yourself, your actions, and your own freedom. But this is not the path chosen by instrumental reason as a means of domination and control in order to make the human being merely an element in charge of a mechanism. A human being built in this way cannot, and would not, have the capacity to come up with the creative, innovative answers which we are looking for, as he or she would act from morality rather than from ethics. From the humanist perspective, morality is not conceived as something negative in itself. It is seen as opposed to ethics, since morals refer to laws, norms, values, and behaviors which are defined by something, or someone, external: institutions, culture of the masses, religion, ideologies, economic pressure. All these factors seek to internalize within individuals, subjecting them, defining them, regulating them in the way that endogenous neoliberalism has done. The individual who regulates appears as an authority. Whoever disobeys is disapproved of by the group and can even be expelled from the community.

Furthermore, morality does not allow questioning of its own content or of its norms. It creates a comfort zone. It is not necessary to risk looking for answers from one's own autonomy, but requires one to follow what is already pre-established and supported by the community. There is no experience of fear or insecurity. On the other hand, ethics is "reason in action." It involves evaluating, pondering, questioning situations, accepts the possibility of making mistakes regarding judgment or not choosing the best option.

The writings of the afore-mentioned authors aim to understand the failure of reason. How is it possible that ordinary people could commit atrocities in such a banal way? Hannah Arendt wrote about the banality of evil in 1963, in her work Eichmann in Jerusalem. Here, she analyses Adolf Eichmann's responses during his trial in Jerusalem, in which he was accused of the genocide of the Jewish people. He told the court that he had done his duty, that he had carried out the job for which he had been hired, well. He had complied with what the system, and the bureaucracy, demanded of him. This is a perfect example of what morality can do when it adjusts itself to an instrumental form of thought that dictates the best means to achieve an end, an end that does not have to be considered.

In Psychoanalysis of Contemporary Society, from 1955, Erich Fromm exposes how bureaucratism is the enemy of humanism. Both communism and capitalism lead to bureaucracy. People end up becoming "officials" who reduce their questions to the morality of whether I work well or if $I$ do it well-questions asked from instrumental reason-instead of focusing on what is really important, which is the ethics of asking oneself whether I'm doing well. This bureaucratism is what Adorno and Horkheimer, in their Critical Theory, appears as a product of "instrumental 
rationality," where reason is valid as long as it is a means to achieve some end. In this sense an individual within an institution, be it a company or a university, is considered a strategic unit with a purpose. They are required to fulfill certain functions, fear punishment, and be guided by the stimuli designed by the experts who are the new authority.

However, the field of ethics, of autonomy, is what allows human beings to think and perceive themselves as above the conditioning that rewards or punishes them. This is in order to have the ability to see themselves not so much as instituted, but as instituents. This enables institutions to think of themselves as meta-institutions, since they can question themselves and learn.

In short it is clear that, within neoliberalism, there is a diseased form of reason, instrumental reason, which seeks domination and needs human beings who act from morality rather than from ethics. In this way they can be fully constructed as mere obedient instruments even in the face of appalling atrocities and within bureaucratic structures which, as reifying mechanisms, reduce individuals to mere instruments. The human being who assumes their own construction from an ethical standpoint is the only one who can do, and experience, something which is alternative to neoliberal logic. Hence the self-realization of the individual is crucial if we want accurate answers to the serious challenges of the present. But the university has not become aware of this, and it cannot do it if it looks at reality through the lens of "endogenous neoliberalism." Consequently, the first responsibility of the university is to become aware (have critical awareness) of the internalized perspective from which it views reality.

\section{A WORLDVIEW BASED ON THE COMMUNITY OF LIFE (FIRST CERTAINTY) THE EARTH CHARTER}

The Community of Life (CL) is the fundamental certainty on which we can base a new worldview. It appears in the Earth Charter (www.earthcharter.org). At the Earth Summit, celebrated in Rio during 1992, the plan was to present a charter that would regulate the relations of states and human beings with Nature, but an inter-governmental agreement was not reached. However, in 1994, Maurice Strong, Secretary General of the Rio Summit, together with Mikhail Gorbachev, re-started the idea as a civil society initiative and this resulted in the most participatory and inclusive global consultation and drafting process ever in the creation of an international document. "A consensus of shared values had been reached. The official launching of the Earth Charter took place at the Peace Palace in The Hague on 29 June 2000" (Vilela and Corcoran, 2006, p. 21). In 2003, with the support of many countries, UNESCO recognized the EC. Endorsed by thousands of organizations, countries, and individuals, and translated into more than 40 languages, the EC is now widely accepted.

\section{The Earth Charter}

The EC has a Preamble, which includes fundamental statements, 16 Principles and, by way of a conclusion, "The Way Forward."
The 16 Principles, which are interdependent, are divided into four chapters each with four principles. The first is the central chapter: "Respect and Care for the Community of Life." The other three chapters expand on the first. Chapter II. Ecological Integrity. Chapter III. Social and Economic Justice. Chapter IV. Democracy, Nonviolence and Peace. The EC is conceived as a declaration of fundamental ethical principles for environmental conservation and sustainable development. It exceeds what had been said in previous agreements and declarations on the environment.

In the Preamble there are a series of propositions which focus on the values and perspective inherent in the EC. The key statement that supports the EC is: "we are one human family and ..." The perspective assumed by the EC is not from just one human group (social class, religion, race, political party, nationality ...) It assumes the perspective of all human beings. The EC maintains that we are a single human species (decoding of the human genetic code in 2003). Besides being a scientific truth, this is also a legal truth. Article 2.1 of Human Rights states that everyone has the rights and freedoms therein proclaimed "without distinction of any kind, such as race, color, sex, language, religion, political or other opinion, national or social origin, property, birth, or other status" (http://www.un. org/en/universal-declaration-human-rights/). The facts indicate that we have failed to place ourselves in this context, at this level of consciousness. We have serious problems of division and class, in addition to ideological, ethnic, economic, social, and belligerent confrontations ... These conflicts give rise to a humanity which is split into opposing groups which prevent us from seeing ourselves and living as a single humanity.

The second part of this Earth Charter's statement is that, in addition, we are: "... one Earth community with a common destiny." This perspective exists at an even more inclusive level, in order to integrate all living beings. This Earth community is the "Community of Life." We need to raise two levels of consciousness in a generation, to extend the inclusiveness of our identity to these two great dimensions: (1) that of all human beings and (2) that of all living beings so as to solve our serious global socio-ecological problems. It is focused on expanding our identity to the point that we feel united with the entire terrestrial community, to the Community of Life, the backbone of the EC.

The central message of the Charter is completed with principle 2 of the first chapter: "Care for the community of life with understanding, compassion, and love" in "Earth, our home" (Preamble). From this perspective everything is redefined. It is not the same talking about rights, citizenship, development, common good, peace, ethics, economy, coexistence, etc., from the only reference of the human family than from the entire CL. Everything changes from the perspective of the CL, and that change implies a new worldview which is at the true heart of the EC.

The concept of citizenship extends from the human world to a citizenship shared with all living beings. The idea of development must ensure, as a fundamental criterion, harmony with the rest of life. Common good would be defined in terms of the community of all beings on Earth. Peace must also be a peace with Gaia. Economy must be cyclical, decarbonised, with zero emissions, 
and mindful not to exceed the regenerative possibilities of the Earth. This means a closer connection with nature, simpler ways of living and consuming in a much more responsible way. As the EC states, at the end of the Preamble, "when basic needs have been met, human development is primarily about being more, not having more." This is, therefore, a form of economy which is subject to politics, and not just to human ethics, but to the broader ethics of the Earth. This is an ethics of caring, which is not anthropocentric, but ecocentric. We are that ethical thread in the fabric of the Community of Life, with the function of caring for the planet... (Fernández-Herrería, 2018).

\section{The Gaia Theory}

Faced with the mechanistic and colonial view of nature, a novel scientific conception arises: the Gaia Theory. This is implicit in the statement of the EC Preamble: "Earth, our home, is alive with a unique community of life." This theory was formulated by Lovelock (1979), an atmospheric chemist, and was immediately supported and complemented by Margulis and Sagan (2002) with her line of research. This research was based on demonstrating the huge importance of bacteria in the chemical transformations of the biosphere. Lovelock was forced by the facts to postulate a global self-regulating mechanism of the Earth system (Lovelock, 1987, 1990; Margulis and Sagan, 2002).

This theory holds that life does not find the right conditions for its evolution on Earth, as claimed by the classical theory of evolution (Neo-Darwinism). It is life itself that creates these favorable conditions for its existence, making the environment, generating it, keeping it, shaping it, and changing it. This in turn feeds back new life, which evolves and changes in that environment (Fernández-Herrería and Martínez-Rodríguez, 2020). Consequently, the Gaia Theory dissolves the differences between what is organic and what we consider inorganic, thus giving rise to highly complex inter-influences which we are now beginning to understand. This network inter-relates microorganisms, plants, and animals with the soil, the oceans, and the atmosphere, all functioning as a living super-organism: Gaia. She, through collective, interdependent, and cooperative work, is capable of regulating herself in order to adapt and maintain an environment optimal for life (Lovelock, 1987; Margulis and Sagan, 1997; Margulis, 1998).

Margulis introduced the theory of endosymbiosis, which is her main contribution to the Gaia Theory. It holds that all the cells of plants and animals (eukaryotes) have been formed by symbiotic union of bacteria (prokaryotes). This highlights the importance of cooperation in the general plan of life, as opposed to Neo-Darwinism which emphasizes random mutations and natural selection based on competition. Margulis (1998) argues that the evolutionary process is guided by symbiosis, stating that cooperation between organisms and the environment is the driving force of natural selection, rather than competition between individuals. According to this author, Darwin's view is incomplete rather than incorrect. Symbiogenesis, as an explanatory theory of evolution, in addition to being a revolutionary theory is also attractive, since it places cooperation at the center of the functioning of the Earth's community.
The Gaia Theory has already earned the respect of the scientific community. There are different interpretations of the Gaia Theory. The holistic perspective, cooperation, the common good of the Earth community, participation, the transversal interexistence which intertwines us, the sense of community, coresponsibility, the networks of inter-influences ... all characterize the concept of the Gaia Theory. This is very different from the previous mechanistic paradigm, which seeks to tame nature. This is what instrumental reason does. It is the mentality of white people: we often have to destroy to "understand."

\section{"CARE FOR THE COMMUNITY OF LIFE WITH UNDERSTANDING, COMPASSION, AND LOVE" THE PEDAGOGY OF CARE FOR A TRANSFORMATIVE LEARNING AS A PATH TO WISDOM (SECOND AND THIRD CERTAINTIES)}

Chapter 6 of Heidegger's Being and Time, 1926, is dedicated to analyzing "The care as the being of Dasein." According to Heidegger (1971), care is the essential way of being, of Dasein, of being there, of being-in-the-world which is the human being. It is irreducible to any other previous category. It alludes to the way in which a being is structured and how it manifests itself. Care, according to this perspective, would belong to the essence of the human being.

Caring for the Community of Life, which includes us, requires us to "build democratic societies that are just, participatory, sustainable, and peaceful" (principle 3) and doing so with "understanding, compassion, and love" (principle 2). This means integrating, symbolically, "head," "heart," and "hands" (understanding love as a committed action). It implies a synthesis of a loving and empathic intelligence, which leads us to action, and an epistemology of integration, an experience of these other intelligences. In addition to cognitive intelligence, we have emotional, social, ecological, and spiritual intelligences (the last one not to be confused with the religious belief). The spiritual is understood as in line with the thinking of Capra (1998), which coincides with that of Boff (2001, p. 90) "as that attitude by which the human being feels linked to the whole.”

This synthesis, or integration, implies an epistemology which is a living experience which places us at the doors of wisdom. The philosopher Anne W. Schaef (1995, p. 53-54) states: "Knowledge that is abstracted and disembodied from parts of our brains, and unconnected to our beings, may be useful for creating technology, and it will never move us to wisdom." Knowledge is not enough. Rather, it is dangerous if it is not coupled with compassion, as shown many times throughout history. Louis Farmer, Onondaga elder, and a member from the Iroquois Confederation, conveys to us, through Schaef (1995, p. 20), the message which says that "without the balance of the heart, the mind is an enslaving master. Only through the heart can the mind be balanced." Only if we are willing to learn with our whole beings can we use information wisely, because the mind cannot be trained without the heart and, indeed, without the whole being. 
Mind divides, objectifies, splits subject from object, while heart unites. Knowledge is not, therefore, a centrifugal act of possession of the object (epistemology of the hunter), but a way of growing in harmony with the environment. We can find this in the wisdom of the indigenous peoples. "Knowledge can be learned. Wisdom must be lived" (Schaef, 1995, p. 20). But education and university are still anchored in the paradigm of modernity which privileges rational and cumulative knowledge. "Education is not the filling of a pot, but the lighting of a fire," said William Yeats, poet and playwright. In reality human development, which is synonymous with integral learning, is a process that occurs from within the human being.

Nicholas Maxwell (1984, 2014), a British philosopher, proposes a revolution in the academic world in which its activity focuses not only on knowledge but goes beyond, in the search for wisdom. This is because science and technology have failed in solving the great problems of humanity. We urgently need a radical change in scientific and technological research, so that it is directed unambiguously toward the goal of survival. We have a militarized science but it is not exactly at the service of humanity, as Maxwell would like. The goals of science and technology must be reformulated. If we want to work on wisdom at university level, and not turn it into a study of wisdom, we have to make a "turn" toward the person, toward the individual him/herself.

The traditional paradigm of the Age of the Enlightenment conferred an absolute value on reason. It ignored what Pascal said in his Pensées when speaking of the logic of the heart and its "reasons," unknown to reason. Today we have an inflation of reason, especially instrumental and analytical reason, to the detriment of other intelligences. We can consider the ethics of care, which is the most important feminist moral theory of recent years, and its educational translation into an Ecopedagogy as Pedagogy of Care. This focuses on three major fields: caring for ourselves, caring for others and caring of the planet (Fernández-Herrería and López-López, 2010). Care is the opposite of disinterest, indifference, forgetfulness. Caring, as a way of being, implies concern and activity, responsibility, sensitivity, closeness, affective commitment to the other, and to the world. This is what makes us fully human. We are born to care. The ultimate effect of this ethics of care will be peace on Earth and with Earth.

The Pedagogy of Care should have, as its main objective, the experiential learning of the essential, radical experience of our interconnection and interdependence with the CL. It is feeling that we are one more thread (the ethical, caring thread) within the complex weave of the Earth Community (Fernández-Herrería, 2018). This is an essentially spiritual goal, belonging to the realm of wisdom which profoundly transforms our consciousness. It would be the fundamental, truly transformative learning that we, as humanity, would have to carry out. It is a spirituality that will reconnect us with the world. This is what the West has forgotten. A "conversion to life" is an essential path of wisdom for the current global situation. For this reason ethics, wisdom, and ecology cannot be seen as external interventions aimed at solving socio-ecological challenges, unless we want to convert them into moral, legal, or purely formal actions.
Sterling (2010) argues that "education for change," that is, those forms of education with "adjectival adjuncts" (Martin, 1996), such as education for peace, for sustainability, gender ... should focus less on labels and more on the meaning of the times in which we are living. We understand that Sterling's plea goes deeper by facilitating a change in worldview. This is what should underlie the different forms of education for change. What is the problem? Sterling (2007) looks to Bateson (1972) for an answer. Bateson distinguished three types of learning related to social change: Learning I, a maintenance, adaptive learning; Learning II, which creates profound changes in the systems. Sterling argues that this kind of learning involves a questioning that readjusts our conceptual frameworks and basic assumptions. Finally, there is Learning III. For Bateson, this is learning which leads to a radical change in worldview. He identifies it with transformative learning, which involves a structural change in the basic premises of thought, feelings, and actions. It is a shift in consciousness which, as Sterling argues, dramatically and permanently alters our way of being in the world.

Consequently, if we want a form of learning, which is capable of changing our civilization, we will need to promote Learning II. But there is a condition, as Bateson argues and Sterling assumes. It is that, in order to access this kind of learning, educators should be at the Learning III level. However, there are not enough educators at this level of learning. So, when we come across a document like the EC, it is often downgraded to a mere programme of methodological change which may be innovative, but which does not incorporate the potential for transformative learning: changing the worldview. The explanation for this degradation is that each one "adapts," "reduces" the content of the EC to their own level of consciousness. Actually, the EC implies a new state of consciousness. Boff (2008) speaks of a new re-enchantment of the world, an ethical revolution, the expansion of our sense of identity: the "ecological Self," as defended by Seed, Macy, Fleming, Naess, and all deep ecology (Macy and Brown, 1998). This is a global biophilic consciousness (Fernández-Herrería and Martínez-Rodríguez, 2016), "a change of mind and heart," "a new beginning," as stated in the EC, specifically in "The Way Forward."

When we pose a problem the answers are generally sought in the external environment (change of economic, social, institutional structures ...). However, in traditional Eastern thought it is typical to hold like Gandhi: "If you want to change the world, change yourself." The global nature of our problems forces us to be intercultural, but not in a superficial way. Cultures have different ways of expressing reality. Interculturality is communion with other experiences of the world, with other ways of feeling, perceiving, and sharing reality. We need to understand them because they can complement, or improve, our own. If we continue to follow the traditional Eastern perspective, we can look to Krishnamurti, an unusually lucid philosopher of Indian origin, who maintained that:

The world is the projection of myself. What I am, that is the world, because the world is not different from me (...) The world and I are two separate entities. Society is myself. There are no two different processes. The world is an extension of myself, and to 
understand the world I must understand myself. (Krishnamurti, 1963, p. 225).

In other words: "the movement of the external is, undoubtedly, connected with the flow of the internal. Both are the same thing (...). The society we have created is the external, and then the internal becomes a slave of that society" (Krishnamurti, 1989, p. 177-178). Life is an unfragmented whole, a unitary process. "As long as we consider ourselves as entities separated from society we will never understand society, or ourselves, and we will always be in conflict with society" (Krishnamurti, 1977, p. 63).

Trying to solve outer problems without solving the inner ones is, as previously stated, a waste of time and represents a fall into hopelessness. How do we apply this to the change we demand of the university? Let us find an answer in the following text by Ken Wilber, who is considered the father of transpersonal psychology:

The ecological crisis -or Gaia's main problem- is not pollution, toxic dumping, ozone depletion, or any such. Gaia's main problem is that not enough human beings have developed to the post-conventional, world-centric, global levels of consciousness, wherein they will automatically be moved to care for the global commons (Wilber, 2000, p. 137)

In short, let us work on that single movement, starting from both sides: our-own-change-while-we-change-the-university ${ }^{1}$, and vice versa.

It is very typical of the Western mentality to pose problems and try to solve them in a rational way. This is the direction that Western philosophy has taken since Ancient Greece. Therefore, it was linked to logos when it was born, and was an overcoming of myth. The love of wisdom (philos-sofos) is solved in the West as a "talkistic", argumentative, symbolic, and speculative practice. However, Eastern philosophical traditions (Indian more than Chinese) look at reality, its investigation, involving the whole human being in an operational practice aimed at the transformation of his/her consciousness, of his/her life. Reasoning alone is an inadequate way of penetrating fundamental issues, as shown by the dead ends into which the rationalist monopoly of the mind has put us, thus evidencing the tyranny of reason. The best method is the mode of existence, the path that becomes methodology itself, and which opens life to truth, rather than to propositions that only seek to objectively describe the real. It is the totality of the human being, and not only of his/her intellect, which can walk this path. We must have an experiential learning and, in our case, a learning based on our reconnection with the Community of Life, which involves a change of "mind and heart," as advocated by the EC. This is Learning III, a really transformative learning, which implies a change in worldview. Just thinking about it is not enough. We need the wisdom of experiencing reconnection. We have lost our reconnection with others and with nature because we have lost our reconnection with ourselves.

${ }^{1}$ Hyphens are to show that the internal and the external form a single back and forth movement.
In the King and Schneider's report to the Club of Rome, it was rightly said that "we are rich in knowledge, but poor in wisdom (...). Probably a fundamental outbreak of wisdom can only take place through the internal development of the individual" (King and Schneider, 1991, p. 241). This is an inner culture which is largely forgotten by the educational system. However, an undeniable reaction is taking place worldwide: many groups are cultivating ecology, meditation, spirituality, and carrying out social and ecological activism ... We need an environmental education and, in general, a different education (Jickling and Sterling, 2017).

\section{SOME PRACTICAL CONSEQUENCES}

1. Which vision and procedure?

- We are, here, proposing another way of seeing reality and our place in it. The changes that must take place in universities have to be based on a worldview, otherwise they would be mere practices and disconnected actions which would end up being swept away and colonized by neoliberalism.

- Having a life-centered worldview. Here, the Community of Life and Ethics of Care have been proposed as the central core from which everything is redefined. This view should illuminate our actions, both critical and constructive, and our agreements.

- The "discussion" and decision-making procedure is important. It is not about each individual and small groups defending some positions against others. This would be the traditional method, which does not fit with the way life works. Therefore, the procedure would be the first thing that should be redefined from the Community of Life and its way of acting. We suggest the following: each person issues their proposal, just as life does with its complex and countless exchanges. But, by doing so, they place it in a space which is common and, at that point, it is no longer "theirs." (In this way we move from competition and defense of personal stances to cooperation.) In this space everyone "works on" the proposal in relation to the other proposals. In many ways they complement it, redefine it, embellish it, reposition it ... as life does with the materials it exchanges. Thus, we create, without haste, a work of collective construction which gives rise to moments of silence. Regarding the "inner" part of this work, we should seek mental and emotional relaxation, in a state of observation, free from self-censorship, and letting ideas flow. In this way creativity can be expressed. Regarding the fruits of the procedure, we should not expect a logical Cartesian design. Life does not work in this way. Its "logic" is complex, "dirty", intricate, it has intersections, overlaps and networks on different levels. This is to be expected. With the practice of the proposals, redundancies will be eliminated and areas of weakness will become visible. This could be the functioning of a "community of vision".

- This transformative Learning III, which constitutes a change from the Community of Life as an experiential and 
integrative (head, heart, and hands) learning, is not fully teachable. We can establish the means, prepare the stage with good experiences and reflections, but that learning arises from within each individual. We only help in this delivery, as Socrates suggested.

2. What structure and functions would the university, as an Organization, have?

- Become critically aware, using the procedure described, of how education, and specifically universities, are seriously threatened by neoliberal globalization. It is important to identify the ways in which the business management of the university is specified according to the characteristics of the NPM (see above), and to agree on which of these characteristics can be reversed. We can eliminate some of them, but we have others such as decentralization, flexibility, creativity, adaptability, wake state administration, less bureaucratic organizational forms... which seem advanced and innovative to us. Let us use these characteristics of the system against the system itself, reversing its meaning, as with judo. In this way they would be redefined in that worldview which places all life at the center of social and institutional organization; in this case, the university. Thus creativity, for example, would be at the service of a university community that seeks socio-economic and ecological justice in our common home, the planet.

- This will entail general institutional changes: the university must dissociate itself from the instruments, institutions, regulations, practices, organizational style, management, objectives, functions... which promote a colonized university. We call for the promotion of a practice based on ethics, not morals or instrumental thought and action. It will also entail creating chairs, seminars, innovative projects, investigations ... in order to promote the paradigm shift, in addition to its practical, structural, organizational, curricular, and didactic implications in higher education and in individuals. Universities must form networks in order to become collectively aware of this and act accordingly.

- We can apply the principles that make ecological systems sustainable to universities. This can be done by following the CFE, which highlights concepts such as interdependence, integrity of the system, biodiversity, cooperation and association, appropriate size, common goods, life cycles, networks and flows, among others. According to Capra (2005), we should perceive our social organizations, our universities, our cultures, human communities, like any other living organism: as dynamic communities in evolution processes. In another publication, Capra (2013) argues that, if we use nature as a source of knowledge, we can identify existing patterns in ecosystems in order to apply them to our social institutions, which are also seen as ecosystems.

3. How can personal transformation and the path to wisdom be promoted?
- Working on the personal aspect and interculturality, to which this work gives great importance. The academic contents are important but, even more important, is that the university promotes the development of the individual by means of the search for self-realization. This can be done within the context of humanistic and transpersonal psychology, working with group techniques, gestalt, relaxation, visualization, creative imagination, expressive arts (theater, music, dance, yoga...), meditation, silence, commitments to the community, and social and ecological activism... This entails that turn inwards, toward the inner person. It introduces us into the trans-verbal and transcultural dimensions of human development and, consequently, of education and wisdom. In our educational system there is no wisdom, and this is why it is so full of words. Furthermore, it lacks silences as a way of opening up transpersonal spaces. We also need to learn to listen, to observe from silence without judgment or evaluation, without words, without choice, without manipulation of what is observed. A specific practice would be the development of sensory awareness in nature. At the Faculty of Education Sciences of the University of Granada, some of these methodologies have been undertaken for years. They include relaxation, creative imagination, sensory awareness in nature, and meditation. ${ }^{2}$ A fascinating field that universities should address, and that would connect us with the great wisdom traditions of humanity such as Buddhism, Taoism, Zen, indigenous peoples, and shamanism...

- Regarding the ethics of care, practical experiences can be undertaken in three areas, since caring is learned by caring. This type of practice should be considered in universities, since it supposes an integrating exercise of the various intelligences. It would mean caring "with understanding, compassion, and love" and thus we introduce ourselves to the path of wisdom. Let us start by taking care of ourselves. This involves healthy eating, exercise, rest, eliminating habits like harmful consumption ... taking care of emotions and thoughts, so as not to harm, and taking care of actions in different contexts. We must take care of the lives of others: helping to cover their basic and material needs. We must look after them and their lives by listening, hugging, dialogue, support, searching for justice, volunteering, social activism ... (Martínez-Rodríguez and Fernández-Herrería, 2017). We must also take care of things and Mother Earth. We must ensure adequate consumption, reuse, and recycling, reduction of the ecological footprint, environmental activism, implication in networks ... This includes service-learning, which

\footnotetext{
${ }^{2}$ The publications are in Spanish. Those interested in them can contact Alfonso Fernández-Herrería: alfonsof@ugr.es. On the occasion of the celebration of the end of the decade of Education for Sustainable Development, a book was published by Earth Charter International, based in Costa Rica. It was in English and Spanish, and included a selection of good practices in accordance with the Earth Charter carried out in different countries. Two were chosen among those carried out at the University of Granada. This is the link: https://earthcharter.org/library/the-heartof-the-matter-infusing-sustainability-values-in-education/ (English).
} 
integrates learning with social commitment by performing a service to the community.

- Promoting critical reflection processes on a personal level in order to analyse the influence of "endogenous neoliberalism" in the construction of an individual's subjectivity. An example of this colonization is in professional careers, where teachers become entrepreneur of themselves and self-exploit in order to achieve an increasingly demanding curriculum, with teaching itself being side-lined. When teachers fail to spend the maximum of time on increasing their "productivity," they have problems and feel guilty.

4. What should be done at the curricular level?

- Given that an education colonized by the neoliberal globalization transforms people into mere instruments through the professional curriculum, profound changes must be made in the design, development, and assessment of the curriculum. It must focus on the Community of Life and not on market forces. It has to foster an interdisciplinary and transdisciplinary epistemology in order to avoid a curricular fragmentation that transforms reality into a set of subjects

- The influence of education involves not only what is academically done but also, and in a very relevant way, how it is worked and the context in which it is carried out. As an example of this, we refer to the education that is undertaken in the Center for Ecoliteracy (CFE), based in California and co-founded by Fritjof Capra. This education aims to present a sustainable educational model for formal education. For reasons relating to lack of space, we make only one comment and refer the reader to this publication (Martínez-Rodríguez et al., 2018). In it, the characteristics of its educational model are contrasted with the theoretical principles of the NPM as an instrument for the implementation of neoliberalism. The CFE is based on four great principles: (1) Nature is our teacher, where ecological literacy is the unifying principle of the curriculum, which is sustained on six premises. Promoting "Collaborative Learning" which develops empathic commitment in addition to enriching the educational process in many ways. (2) Sustainability is a community practice. (3) The real world is the optimal environment for learning. Hence the promotion of the strategy of the Project Based Learning, direct experiences in nature, community activities, and reflection on the constructed environments. (4) Sustainable living is rooted in deep knowledge of the environment. This implies a profound change in the organization of learning, in spaces and times, and its typical time fragmentation in subjects. It involves collaborative and experiential methodologies based on real situations in the natural world and in the community. All this is typical of projects which have a systemic holistic view, with practice in empathy, using different intelligences and seeking a commitment with the socio-natural environment. In this way, the foundations of the connection with the socio-natural environment, which we have repeatedly highlighted throughout this work, are laid. The CFE is an advanced example of how, in general, universities should change.

- Other practices: community coexistence retreats in nature in order to carry out different educational activities, learning about creative means of conflict resolution. Training of students to become mediators, gaining knowledge from indigenous cultures and their stories of wisdom. We refer here to the research carried out by Cutanda (2020) in which, in its practical section it proposes, among other things, an educational use of traditional stories - collected from around the world-as key resources for the transmission of a worldview centered on the Community of Life.

\section{What kind of teacher training?}

- The university should have a commitment to a new form of teacher training, one which is different from normative and technological approaches constructed from a fragmented view of reality, disconnected from practice and oriented toward an effective teacher model. This has led teachers to become a de-professionalized, vulnerable group, dependent on the official and hegemonic discourses colonized today by neoliberalism. From these approaches, teacher training programmes have proven incapable of responding to the profound changes which are affecting educational institutions and teaching (Hargreaves and Lo, 2000). We need to rethink the way in which university teachers are prepared, and adopt critical approaches which are sensitive to global problems. This should include biophilic approaches which take into consideration their academic, political, ethical, and personal development training as a key factor in responding to the complex changes which affect individuals and contemporary contexts.

- These approaches, backed by more comprehensive and transformative training models, should promote reflective, collaborative, and inquiring dynamics within the teaching profession. This should reinforce their integral development, their permanent commitment to innovation in their professional activity in addition to the improvement of reality from the perspective of this new vision of the Community of Life.

- The adoption of these approaches and models from this new view has a direct impact on teacher training plans and proposes the reconstruction of teachers' professional identities within the university context, as well as in organizational cultures. It would entail, among other issues, reconsidering the contents of the training proposals. This would be reinforced by the inclusion of ethical, emotional, ecological, and intercultural aspects. Also, it would institutionalize new ways of learning to teach which are more inter and transdisciplinary and based on coordination and collaboration (project learning, problembased learning, service learning,...). All this must always spring from an ethical framework, one which has, at its 
core, the vision of the Community of Life, and its care the backbone of the commitments and duties (in relation to the students, colleagues, profession, university, and environment). This would define the teaching profession in University.

6. What kind of leadership?

- Far from the performance of an authoritarian, personalized, and eminently bureaucratic leadership, current trends advocate a more pedagogical and distributed form of leadership, a leadership committed to democratic values and the fight against structural and cultural inequalities (Ryan, 2012; Shields, 2013; Harris et al., 2017). This type of leadership could be a good ally in the need to reverse the presence of neoliberalism in the university, if it is accompanied by a commitment to ecological values. Leaders are needed in order to strengthen the commitment of universities to sustainability problems and address issues related to the most disadvantaged in society (development of aid programs, aid to marginalized groups. and those at risk of social exclusion,...). There is a need for leaders who are capable of promoting teaching innovation projects sensitive to the many existing diversities, and expressing support for research projects that contribute to guaranteeing inclusion and social justice for all. This is in addition to fostering greater sustainability on the planet, as required by the 2030 Agenda for Sustainable Development (UNDP, 2015), and, more radically, the worldview proposed by the Earth Charter.

\section{FINAL REFLECTIONS}

The growing socio-economic inequalities, and the ecological devastation of the Earth, show that we currently face a paradigm in decline. Mechanistic rationalism, together with anthropocentrism, reduces nature to a mere economic resource

\section{REFERENCES}

Ball, S., and Youdell, D. (2007). "Preliminary report: hidden privatisation in public education," in Education International $5^{\text {th }}$ World Congress, July 2007. Available online at: http://www.campaignforeducation.org/docs/privatisation/Endogenous \%20Privatization\%20Stephen\%20Ball_ENGLISH.pdf

Bateson, G. (1972). Steps to an Ecology of Mind. Chicago, IL: University of Chicago Press.

Bauman, Z. (2008). Los Retos de la Educación en la Modernidad Líquida [Challenges of Education in Liquid Modernity]. Barcelona: Gedisa.

Bernal, J., and Vázquez, S. (2013). La Nueva Gestión Pública: el desembarco de las ideas neoliberales con la LOMCE [The New Public Management: the advent of neoliberal ideas with the LOMCE]. Rev. Temp. $16,35-58$.

Boff, L. (2001). Ética Planetaria Desde el Gran Sur [Planetary Ethics from the Great South]. Madrid: Trotta.

Boff, L. (2008). La opción-Tierra [The Earth Option]. Santander: Sal Terrae.

Canaan, J. (2013). Resisting the English Neoliberalising University: what critical pedagogy can offer. J. Crit. Educ. Policy Stud. $11,16-56$.

Capra, F. (1998). La Trama de la Vida [The Web of Life]. Barcelona: Anagrama. to be exploited, and people to instruments trapped within the mechanism of neoliberalism. Instrumental reason, as the epistemology of domination, is endangering human survival. A new worldview, the paradigm of care specified in the Earth Charter in the context of the planet as a living superorganism, in alternative movements... must replace the decadent paradigm of domination that emerged from the Enlightenment. A new ethic, the ethics of care, of solidarity, of shared responsibility, compassion, reverence, and veneration before the mystery of life, drives us with passion toward a new way of living in the world, with the motivation to contribute to the healing of the planet.

In recent centuries, humanity has exiled itself from the Community of Life, placing itself above and against it. We have disconnected ourselves from the fabric of life and from others. This process of alienation and uprooting has made us, personally and socially, ill (depression, anguish, lack of meaning, stress, chronic fatigue, insomnia, drug addiction, alcoholism, suicide...). We live as lost souls-a mere element among othersmanipulated by the Market which has become the Absolute in these times of neoliberal globalization.

We need to get to the root and have a significant "critical mass" in order to take a leap toward an empathetic global and biophilic consciousness, in just one generation, if we want to respond to the serious socio-ecological problems of humanity (Fernández-Herrería and Martínez-Rodríguez, 2019).

\section{DATA AVAILABILITY STATEMENT}

The original contributions presented in the study are included in the article/supplementary material, further inquiries can be directed to the corresponding author/s.

\section{AUTHOR CONTRIBUTIONS}

All authors listed have made a substantial, direct and intellectual contribution to the work, and approved it for publication.

Capra, F. (2005). “Speaking nature's language: principles for sustainability," in Ecological Literacy: Educating our Children for a Sustainable World, ed S. Michael (San Francisco, CA: Sierra Club Books), 18-29.

Capra, F. (2013). Deep ecology: educational possibilities for the twenty-first century. NAMTA J. 38, 201-217.

Comins, I. (2016). La filosofía del cuidado de la tierra como ecosofía [The philosophy of earth's care as ecosophy]. Daimon 67, 133-148. doi: $10.6018 /$ daimon/201501

Commisso, G. (2013). Governance and conflict in the university: the mobilization of Italian researchers against neoliberal reform. J. Educ. Policy 28, 157-177. doi: 10.1080/02680939.2012.695805

Cutanda, G. (2020). "Changing world-views through a stories collection and the Earth Charter," in Storytelling for Sustainability in Higher Education: An Educator's Handbook, eds P. Molthan-Hill, H. Luna, T. Wall, H. Puntha, and D. Baden (Abingdon-on-Thames: Routledge), 29-37.

Darder, A. (2012). Neoliberalism in the academic borderlands: an ongoing struggler for equality and human rights. Educ. Stud. 48, 412-426. doi: 10.1080/00131946.2012.714334

De Lissovoy, N. (2013). Pedagogy of the impossible: neoliberalism and the ideology of accountability. Policy Fut. Educ. 11, 423-435. doi: 10.2304/pfie.2013. 11.4 .423 
Du Gay, P. (1996). "Organizing identity: entrepreneurial governance and public management," in Questions of Cultural Identity, eds S. Hall and P. Du Gay (London: SAGE Publications), 151-169.

Fernández-Herrería, A. (2018). "Educación para la paz y la sostenibilidad. Experiencias de re-conexión con la comunidad de la vida" [Education for peace and sustainability. Experiences of reconnection with the community of life], in Ética Aplicada. Experiencias en Educación Universitaria, ed C. Guadalupe García (México, D. F.: Torres Asociados), 11-53.

Fernández-Herrería, A., and López-López, M. C. (2010). La educación en valores desde la Carta de la Tierra. Por una pedagogía del cuidado [Values education from the Earth Charter. For a pedagogy of care]. Rev. Iberoamer. Educ. 53, 1-19. doi: $10.35362 /$ rie 5341722

Fernández-Herrería, A., and Martínez-Rodríguez, F. M. (2016). Deconstructing the neoliberal 'Entrepreneurial Self': a critical perspective derived from a global 'biophilic consciousness'. Policy Fut. Educ. 14, 314-326. doi: $10.1177 / 1478210316631709$

Fernández-Herrería, A., and Martínez-Rodríguez, F. M. (2019). The earth charter as a new worldview in a post-neoliberal world: chaos theory and morphic fields as explanatory contexts. World Fut. 75, 591-608. doi: 10.1080/02604027.2019.1634417

Fernández-Herrería, A., and Martínez-Rodríguez, F. M. (2020). "Planetary ethics beyond neoliberalism: the earth charter's 'community of life," in The Routledge Handbook of Transformative Global Studies, eds $\mathrm{H}$. Hosseini, J. Goodman, S. Motta, and B. Gills (London: Routledge), 273-286.

Foucault, M. (2008). The Birth of Biopolitics. New York, NY: Palgrave Macmillan.

Furlong, J. (2013). Globalisation, neoliberalism, and the reform of teacher education in England. Educ. Forum 77, 28-50. doi: 10.1080/00131725.2013.739017

Goodman, R. T. (2012). The New Taylorism: hacking at the philosophy of the university's end. Policy Fut. Educ. 10, 665-673. doi: 10.2304/pfie.2012.10. 6.665

Gruening, G. (2001). Origin and theoretical basis of New Public Management. Int. Publ. Manage. J. 4, 1-25. doi: 10.1016/S1096-7494(01) 00041-1

Han, B. (2019). La sociedad del cansancio [The Burnout Society]. Barcelona: Herder.

Hargreaves, H., and Lo, N. (2000). Una profesión paradógica: la docencia al comenzar el siglo [A paradoxical profession: teaching at the turn of the century]. Perspectivas 30, 181-196.

Harris, J., Carrington, S., and Ainscow, M. (2017). Promoting Equity in Schools. Collaboration, Inquiry and Ethical Leadership. Abingdon: Routledge.

Harvey, D. (2005). A Brief History of Neoliberalism. Oxford: Oxford University Press.

Heidegger, M. (1971). El Ser y el Tiempo [Being and Time]. México: FCE.

Hellberg, S., and Knutsson, B. (2018). Sustaining the life-chance divide? Education for sustainable development and the global biopolitical regime. Crit. Stud. Educ. 59, 93-107. doi: 10.1080/17508487.2016.11 76064

Horkheimer, M., and Adorno, T. W. (2002). The Dialectic of Enlightenment. Stanford, CA: Stanford University Press.

Hursh, D., and Wall, A. F. (2011). Repoliticizing higher education assessment within neoliberal globalization. Policy Fut. Educ. 9, 560-572. doi: 10.2304/pfie.2011.9.5.560

Jickling, B., and Sterling, S. (2017). Post-Sustainability and Enviromental Educatión. London: Palgrave Macmillan.

Kincheloe, J. L. (2007). "Critical pedagogy in the twenty-first century: evolution for survival," in Critical Pedagogy: Where Are We Now? eds P. McLaren and J. L. Kincheloe (New York, NY: Peter Lang), 9-42.

King, A., and Schneider, B. (1991). La Primera Revolución Mundial. Barcelona: Plaza y Janés.

Krishnamurti, J. (1963). Comprensión Creadora [Creative Understanding]. México: Editorial Krishnamurti.

Krishnamurti, J. (1977). Sólo la Verdad Trae Libertad [Only Truth Brings Freedom]. Buenos aires: Kier.

Krishnamurti, J. (1989). El Último Diario [The Last Diary]. Barcelona: Edhasa.

Leistyna, P. (2007). "Neoliberal Non-sense," in Critical Pedagogy: Where are we now? eds P. McLaren and J. L. Kincheloe (New York, NY: Peter Lang), 97-123.
Loh, J., and Hu, G. (2014). Subdued by the system: Neoliberalism and the beginning teacher. Teach. Teach. Educ. 41, 13-21. doi: $10.1016 /$ j.tate.2014.03.005

López-López, M. C., and Crisol, E. (2020). El compromiso de la Universidad de Granada con la internacionalización. Un estudio de caso [University of Granada’s Commitment to internationalisation. A case study]. Sér. Estud. 25, 121-142. doi: 10.20435/serie-estudos.v25i53.1332

Lovelock, J. (1979). Gaia: A New Look at Life on Earth. Oxford: Oxford University Press.

Lovelock, J. (1987). "GAIA: a model for planetary and cellular dynamics," in GAIA, a Way of Knowing: Political Implications of the New Biology, ed W. I. Thompson (Barrington, MA: Lindisfarne Press), 83-97.

Lovelock, J. (1990). The Ages of Gaia: A Biography of Our Living Earth. New York,NY: Bantam.

Macy, J., and Brown, M. (1998). Coming back to life. Practices to Reconnect Our Lives, Our World. Gabriola Islans BC: New Society Publishers.

Maisuria, A. (2014). The neo-liberalisation policy agenda and its consequences for education in England: a focus on resistance now and possibilities for the future. Policy Fut. Educ. 12, 286-296. doi: 10.2304/pfie.2014. 12.2.286

Margulis, L. (1998). Symbiotic Planet: A New Look at Evolution. New York, NY: Basic Books.

Margulis, L., and Sagan, D. (1997). Microcosmos: Four Billion Years of Microbial Evolution. Berkeley, CA: University of California Press.

Margulis, L., and Sagan, D. (2002). Acquiring Genomes: A Theory of the Origins of Species. New York, NY: Perseus Books Group.

Martin, P. (1996). "A WWF view of education and the role of NGOs," in Education for Sustainability, eds J. Huckle and S. Sterling (London: Earthscan), 40-51.

Martínez-Rodríguez, F. M., and Fernández-Herrería, A. (2017). Is there life beyond neoliberalism? Critical socio-educational alternatives for civic construction. Global. Soc. Educ. 15, 135-146. doi: 10.1080/14767724.2016.1195726

Martínez-Rodríguez, F. M., Vilches-Norat, M. A., and Fernández-Herrería, A. (2018). Challenging the neoliberal view of education: the Center for Ecoliteracy as a transformative educational practice. Globalizations 15, 422-436. doi: 10.1080/14747731.2018.1446601

Maxwell, N. (1984). From Knowledge to Wisdom: A Revolution in the Aims and Methods of Science. Oxford: Basil Blackwell.

Maxwell, N. (2014). How Universities Can Help Create a Wiser World: The Urgent Need for an Academic Revolution. Exeter: Imprint Academic.

Merchant, C. (1980). The Death of Nature: Women, Ecology and the Scientific Revolution. New York, NY: Harper and Row.

Navarro, V. (2007). Neoliberalism as a class ideology; or, the political causes of the growth of inequalities. Int. J. Health Serv. 37, 47-62. doi: 10.2190/H454-7326-6034-1T25

Olssen, M., and Peters, M. A. (2005). Neoliberalism, higher education and the knowledge economy: from the free market to knowledge capitalism. J. Educ. Pol. 20, 313-345. doi: 10.1080/02680930500 108718

Peters, M. A. (2007). Foucault, biopolitics and the birth of neoliberalism. Crit. Stud. Educ. 48, 165-178. doi: 10.1080/17508480701 494218

Ryan, J. (2012). Struggling for Inclusion: Educational Leadership in a Neo-Liberal World. Issues in the Research, Theory, Policy, and Practice of Urban Education. Charlotte, NC: Information Age.

Schaef, A. W. (1995). Native Wisdom for White Minds. New York, NY: Ballantine Books.

Shields, C. M. (2013). Transformative Leadership in Education: Equitable Change in an Uncertain and Complex World. New York, NY: Routledge.

Shiva, V. (1991), Abrazar la vida. Mujer, Ecología y Supervivencia [Staying Alive: Women, Ecology and Development]. Montevideo: Instituto del Tercer Mundo.

Sterling, S. (2007). "Riding the storm: towards a connective cultural consciousness," in A Social Learning: Towards a Sustainable World, ed A. Wals (Wageningen: Wageningen Academic), 63-82.

Sterling, S. (2010). Living in the Earth: towards an education for our time. J. Educ. Sustain. Dev. 4, 213-218. doi: 10.1177/097340821000400208

UNDP (2015) Transforming Our World: The 2030 Agenda for Sustainable Development. United Nations. Available online at: https:// sustainabledevelopment.un.org/content/documents/21252030\%20Agenda 
\%20for\%20Sustainable\%20Development\%20web.pdf

(accessed September 2020).

Uzuner-Smith, S., and Englander, K. (2015). Exposing ideology within university policies: a critical discourse analysis of faculty hiring, promotion and remuneration practices. J. Educ. Policy 30, 62-85. doi: 10.1080/02680939.2014.895853

Vilela, M., and Corcoran, P. B. (2006). "Building consensus on shared values. History and provenance of the Earth Charter," in The Earth Charter in Action, ed VV.AA. (Amsterdam: KIT Publishers), 17-22.

Wilber, K. (2000). Integral Psychology: Consciousness, Spirit, Psychology, Therapy. Boston, MA: Shambhala Publications.
Conflict of Interest: The authors declare that the research was conducted in the absence of any commercial or financial relationships that could be construed as a potential conflict of interest.

Copyright (c) 2021 López-López, Martínez-Rodríguez and Fernández-Herrería. This is an open-access article distributed under the terms of the Creative Commons Attribution License (CC BY). The use, distribution or reproduction in other forums is permitted, provided the original author(s) and the copyright owner(s) are credited and that the original publication in this journal is cited, in accordance with accepted academic practice. No use, distribution or reproduction is permitted which does not comply with these terms. 